\title{
PERBEDAAN LATIHAN DAN BAKAT KINESTETIK TERHADAP KEMAMPUAN SMASH BOLA VOLI
}

\author{
I Ketut Agus Artha', Made Suparman ${ }^{2}$ \\ ${ }^{1,2}$ Jurusan Pendidikan Olahraga dan Kesehatan \\ Sekolah Tinggi Keguruan dan Ilmu Pendidikan Agama Hindu \\ Singaraja, Indonesia \\ email: agusartha001@gmail.com, $\underline{\text { imen_nee@yahoo.com }}$
}

\begin{abstract}
Abstrak
Penelitian ini bertujuan untuk menguji pengaruh latihan dan bakat kinestetik terhadap kemampuan smash bola voli. Penelitian menggunakan intake kelas sebagai sampel, sehingga penelitian yang dilakukan adalah penelitian eksperimen kuasi (quasi eksperiment) dengan rancangan pretest-posttest non-equivalent control group design. Subjek penelitian adalah Siswa SD Negeri 1 Pelapuan berjumlah 48 orang. Pengumpulan data dengan angket dan tes kemampuan smash bola voli berbentuk lembar observasi. Metode analisis data menggunakan analisis kovarian (ANACOVA) faktorial $2 \times 2$ dengan bantuan SPSS 22.0 for windows. Hasil penelitian menunjukkan bahwa pada kelompok metode latihan smash bola voli yaitu: $\Delta \mu(K S B V)==6,518$ lebih besar dari $\operatorname{LSD}(\mathrm{KSBV})=4,996$. Nilai ratarata kemampuan smash bola voli pada kelompok (bergerak) secara statistik lebih tinggi dibandingkan pada kelompok (diam). Ditinjau dari siswa yang memiliki bakat kinestetik tinggi dan rendah adalah 6,814 dengan standar deviasi $\mathrm{SD}=2,449$ dengan angka signifikansi lebih kecil dari 0,05.Di samping itu, $\Delta \mu(K S B V)==$ 6,814 lebih besar dari $\operatorname{LSD}(\mathrm{KSBV})=4,996$. Nilai rata-rata siswa dengan bakat kinestetik tinggi secara statistik lebih tinggi dibandingkan dengan siswa yang memiliki bakat kinestetik rendah. Terdapat interaksi antara latihan dan bakat kinestetik terhadap kemampuan smash bola voli merupakan interaksi ordinal (bersilangan). Simpulan dalam penelitian ini adalah terdapat pengaruh signifikan antara perbedaan latihan dan bakat kinestetik terhadap kemampuan smash bola voli siswa SD Negeri 1 Pelapuan.
\end{abstract}

Kata-kata kunci: perbedaan latihan, bakat kinestetik, smash bolavoli

\begin{abstract}
:
This study aims to discuss the interaction of excercise and kinesthetic talent with the volleyball smash. The study used a sampling class, so the research conducted was a quasi (quasi experiment) study with a non-equivalent pretest-posttest design of a control group design. The subjects of the study were students at SD Negeri 1 Pelapuan studying 48 people. Data collection by questionnaire and volleyball smash ability test. The method of data analysis using $2 \times 2$ factorial analysis of covariance (ANACOVA) with the help of SPSS 22.0 for windows. The results showed that the volleyball smash training method group was: $\Delta \mu(K S B V)==$ 6,518 greater than $\operatorname{LSD}(\mathrm{KSBV})=4,996$. The average value of volleyball smash
\end{abstract}


ability in the (moving) group was statistically higher than in the (Silent) group. Judging from students who have high and low kinesthetic talent is 6,814 with a standard deviation of $\mathrm{SD}=2,449$ with a significance number less than 0.05 . Besides that, $\Delta \mu(K S B V)==6,814$ greater than $\operatorname{LSD}(\mathrm{KSBV})=4,996$. The average value of students with high kinesthetic talent is statistically higher than students who have low kinesthetic talent. There is an interaction between differences in training and kinesthetic talent to the ability to volleyball smash is an ordinal interaction. The conclusion of this research is that there is a significant influence between differences in training and kinesthetic talent on volleyball smash ability at SD Negeri 1 Pelapuan students.

Keywords: exercise difference, kinesthetic talent, volleyball smash.

\section{PENDAHULUAN}

Masalah pokok dalam pembelajaran pada pendidikan formal (sekolah) adalah masih rendahnya daya serap peserta didik. Tujuan dalam proses pembelajaran merupakan komponen pertama yang harus ditetapkan dalam proses pembelajaran sekaligus berfungsi sebagai indikator keberhasilan dalam proses pembelajaran. Meskipun sudah dirancang dengan baik pelaksanaan proses pembelajaran sering berhadapan dengan banyak kendala terutama ketika guru akan memberikan kegiatan praktikum, khususnya untuk mata pelajaran pendidikan jasmani.

Isjoni (2010) menyatakan bahwa pembelajaran adalah sesuatu yang dilakukan oleh siswa, bukan dibuat untuk siswa. Pembelajaran pada dasarnya merupakan upaya pendidik untuk membantu peserta didik melakukan kegiatan belajar.

Solihatin dan Raharjo (2007) menyatakan kualitas dan keberhasilan pembelajaran sangat dipengaruhi oleh kemampuan dan ketepatan guru dalam memilih dan menggunakan model pembelajaran. Hal ini berarti, untuk mencapai kualitas pembelajaran yang tinggi pada setiap pembelajaran, maka pembelajaran harus dikombinasikan dengan model pembelajaran yang tepat.

Undang-undang RI No. 20 tahun 2003 tentang Sistem Pendidikan Nasional (Sisdiknas) pasal 37 menyatakan bahwa penjasorkes merupakan salah satu mata pelajaran wajib mulai dari tingkat pendidikan dasar sampai dengan tingkat menengah atas. Jumlah jam pelajaran dengan durasi 1 jam pembelajaran diatur dalam Permendiknas No. 22 Tahun 2006 berkisar antara 2-4 jam dan 35-45 menit per minggu.

Depdiknas

Pendidikan jasmani, olahraga dan kesehatan (penjasorkes) adalah proses pendidikan yang memanfaatkan aktivitas jasmani yang direncanakan secara sistematik, terencana, dan terarah yang bertujuan untuk mengembangkan dan meningkatkan individu secara organik, neuromuscular, perseptual, kognitif dan emosional. Untuk mendongkrak kondisi penjasorkes nasional yang belum ideal diperlukan kebijakan dan langkah pengembangan sampai di tingkat satuan pendidikan secara 
nyata, efektif dan konsisten. Salah satu terobosan yang dapat dilakukan adalah dengan mewujudkan model pembelajaran yang unggul dan memungkinkan di terapkan di sebagian besar satuan pendidikan nasional. Bagi seorang pendidik penentuan model pembelajaran menjadi tugas utama sehingga mampu menciptakan pembelajaran yang bermanfaat dan bermakna (meaningfull learner).

Berdasarkan hasil observasi di Sekolah Dasar Negeri 1 Pelapuan, dalam materi pelajaran permainan bola voli (smash bola voli) ditemukan berbagai kendala, terutama dalam mengubah perilaku yang telah dimiliki oleh peserta didik, mengarahkan perhatian yang fokus pada peserta didik, serta mengembangkan reaksi emosional yang positif bagi peserta didik sehingga hal ini cukup berdampak pada kemampuan belajar secara signifikan. Adapun hasil persentase kemampuan smash bola voli yaitu, siswa yang tergolong kategori tuntas sebesar $27,5 \%$ dan siswa yang tidak tuntas sebesar 72,5\%. Kemampuan smash bola voli dikatakan berhasil atau tuntas apabila berada pada persentase $70 \%$ secara individu dan $80 \%$ secara klasikal. Ditinjau dari hasil penemuan, ditemukan permasalahan pada siswa antara lain: (a) aktivitas siswa dalam mengikuti pelajaran masih rendah dan bersifat inferior, (b) interaksi cenderung satu arah dari guru ke siswa, sehingga mengakibatkan siswa kurang aktif dan kreatif, dan (c) siswa yang lebih pintar jarang yang mau membantu temannya yang kurang mampu kecuali diminta oleh guru. Hal ini kemungkinan di karenakan metode pembelajaran yang diterapkan kurang mampu mengakomodisasi

seluruh perbedaan kemampuan fisik (skill), emosional serta bakat-bakat yang dimiliki siswa.

Dengan menganalisa data tersebut perolehan hasil belajar sangatlah kurang, sehingga hal ini menandakan proses pembelajaran tidak dapat berjalan dengan optimal. Jika hal ini terus berlangsung, maka akan mengakibatkan kegagalan dan kemandegan pada siswa dalam proses pembelajaran.

Dari kajian tersebut perlu adanya pembenahan terhadap pembelajaran yang nantinya dilakukan untuk menciptakan suatu pembelajaran yang efektif, sehingga dapat menunjang pencapaian belajar siswa dengan optimal.Saat ini upaya untuk mencapai prestasi dalam olahraga merupakan hal yang cukup rumit dan kompleks, karena melibatkan berbagai faktor yang berpengaruh terhadap prestasi itu sendiri.

Pengembangan metodologi latihan merupakan salah satu hal penting yang ikut menentukan pencapaian prestasi dalam olahraga. Peranan ilmu pengetahuan dan teknologi sangat penting bagi pengembangan teori dan metodologi latihan dalam olahraga. Dengan pengembangan teori dan metodologi latihan yang didukung oleh penguasaan berbagai ilmu pengetahuan dalam olahraga seyogyanya mampu meningkatkan kualitas pembinaan dan pelatihan olahraga secara menyeluruh.

Adapun bahan kajian dalam penelitian ini adalah materi permainan bola voli yaitu mengarah pada perbedaan latihan terhadap kemampuan smash bola voli pada siswa Sekolah Dasar Negeri 1 Pelapuan. Disamping untuk 
membantu siswa ke hal lebih bermakna, dalam hal ini dapat pula dikaitkan dengan adanya penyertaan bakat kinestetik yang dimiliki siswa itu sendiri.

Seperti yang diungkapkan Sarwono (1979) menyatakan bahwa, bakat adalah kondisi dalam diri seseorang yang memungkinkannya dengan suatu latihan khusus mencapai kecakapan pengetahuan dan keterampilan khusus. Tedjasaputra (2003) menyatakan bahwa bakat adalah tingkat kemampuan yang tinggi yang berhasil dicapai seseorang dalam keterampilan tertentu, menampilkan bakat dibutuhkan motivasi kuat yang disebut minat, yakni kebebasan seseorang memilih segala sesuatu yang disukai, disenangi dan ingin dilakukan.

Ronald

menyatakan bahwa persepsi kinestetik merupakan fungsi yang berhubungan dengan informasi kinestetik, yaitu informasi yang diperoleh dari gerakan-gerakan otot dan persendian sebagi umpan balik terhadap mekanisme perseptual yang harus dirasakan, dibandingkan dan diidentifikasikan melalui cara yang sama dengan informasi yang diperoleh dari lingkungan sekitar. Dengan kata lain kinestetik adalah keistimewaan pada orang-orang tertentu yang lebih cepat memahami ilmu atau pelajaran dengan aktifitas dibanding membaca dan menghafal. Berdasarkan pandangan tersebut dapat disimpulkan bahwa bakat kinestetik merupakan suatu kecakapan kemampuan ataupun pengetahuan keterampilan khusus yang dimiliki oleh individu yang berlandaskan dari bakat, kecerdasan untuk mengekspresikan ide atau perasaan yang timbul dari dalam diri. Dengan adanya keterkaitan bakat kinestetik tersebut kemampuan, penalaran dan keterampilan untuk meningkatkan kemahiran siswa terhadap kemampuan smash bola voli dapat ditinjau lebih dini. Dengan kata lain bakat kinestetik yang dimaksud dalam hal ini adalah kemampuan bakat yang dimiliki siswa itu sendiri dalam melakukan kemampuan smash bola voli yang cenderung mengarahkan siswa yang memilki bakat kinestetik tinggi dan siswa yang memiliki bakat kinestetik rendah.

dalam $\begin{array}{cr}\text { Adapun yang menunjang } \\ \text { penelitianini }\end{array}$ penelitian yang dilakukan oleh: Sarwa (2010) menunjukkan bahwa mahasiswa yang mempunyai bekal bakat kinestetik lebih tinggi,dalam pembelajaran dengan kondisi yang sama, memberikan prestasi belajar yang lebih tinggi pula. Dari hasil kajian yaitu penerapan bakat kinestetik serta tinjauannya terhadap prestasi belajar yang diterapkan dalam penelitian. Dengan demikian adanya kesesuaian antara penerapan bakat kinestetik yang berhubungan dengan kegiatan praktik pembelajaran yang bermuara pada pencapaian prestasi belajar.

Berpandangan dari penemuan tersebut peneliti terdorong untuk melakukan penelitian dengan judul "Perbedaan Latihan dan Bakat Kinestetik Terhadap Kemampuan Smash Bola Voli Pada Siswa Sekolah Dasar Negeri 1 Pelapuan".

\section{METODE}

Penelitian ini bertujuan untuk menguji pengaruh variabel-variabel bebas terhadap variabel terikat. Penelitian ini menggunakan intake kelas sebagai sampel, sehingga 
penelitian eksperimen yang dilakukan adalah penelitian eksperimen kuasi (quasi eksperiment) .Oleh sebab itu, tidak semua variabel (gejala yang muncul) dan kondisi eksperimen dapat dikontrol secara ketat. Quasi eksperimental design mempunyai kelompok kontrol, tetapi tidak dapat berfungsi sepenuhnya untuk mengontrol variabel-variabel luar yang mempengaruhi pelaksanaan eksperimen (Sugiyono, 2009).

Rancangan penelitian ini menggunakan pretest-posttest nonequivalent kontrol group design, yaitu desain penelitian eksperimen kuasi yang bertujuan menyelidiki tingkat kesamaan antar kelompok dan kemampuan belajarar awal berfungsi sebagai kovarian untuk melakukan kontrol secara statistik. Desain penelitian ini dapat disajikan sebagai berikut:

\begin{tabular}{|c|c|c|}
\hline $\mathrm{O}_{1}$ & $\mathrm{X}_{1}$ & $\mathrm{O}_{2}$ \\
\hline $\mathrm{O}_{3}$ & $\mathrm{X}_{2}$ & $\mathrm{O}_{4}$ \\
\hline
\end{tabular}

Gambar 1. Desain Penelitian

"Pretest-Posttest Non-Equivalent

Control Group Design" (Sugiyono, 2009).

Keterangan:

$\begin{aligned} & \mathbf{O}_{\mathbf{1 , 3}}= \begin{array}{l}\text { Observasiawal (pre-test) } \\ \text { kemampuan smash bola } \\ \text { voli }\end{array} \\ & \mathbf{O}_{\mathbf{2 , 4}}= \begin{array}{l}\text { Observasiakhir (post-test) } \\ \text { kemampuan smash bola }\end{array} \\ & \text { voli } \\ & \mathbf{X}_{\mathbf{1}}= \begin{array}{l}\text { Latihan smash dalam } \\ \text { posisi bergerak }\end{array} \\ & \mathbf{X}_{\mathbf{2}}=\begin{array}{l}\text { Latihan smash dalam } \\ \text { posisi diam }\end{array}\end{aligned}$

Rancangan analisis data yang digunakan dalam penelitian ini adalah ANACOVA faktorial $2 \times 2$. Adapun yang menjadi subjek penelitian adalah siswa siswi SD Negeri 1 Pelapuan berjumlah 48 orang dalam materi kemampuan Smash Bola Voli. Pemilihan sampel dilakukan dengan cara simple random sampling. Pengambilan sampel dilakukan dalam dua tahap. Tahap pertama, menggunakan teknik undian dimana kelas yang muncul dalam undian ada 3 kelas. Dari ketiga kelas dilakukan randomisasi dan kelas yang muncul adalah 2 kelas. Tahap kedua yang dilakukan adalah pengelompokan sampel berdasarkan hasil tes angket bakat kinestetik untuk mengetahui siswa yang memiliki bakat kinestetik tinggi dan bakat kinestetik rendah dengan menerapkan 33\%k elompok atas untuk sampel yang memiliki bakat kinestetik tinggi dan 33\% kelompok bawah untuk sampel yang memiliki bakat kinestetik rendah. Dengan demikian dapat diketahui kesetaraan jumlah pada masing-masing sampel.

Penelitian ini menggunakan tiga variabel yang terdiri dari satu variabel bebas, satu variabel moderator dan satu variabel terikat. Variabel bebas terhadap; (1) Latihan smash bola voli dalam posisi (bergerak dan diam) sebagai variabel bebas, (2) bakat kinestetik tinggi dan rendah sebagai variabel moderator yang mempengaruhi keberhasilan perlakuan, dan (3) kemampuan smash bola voli sebagai variabel terikat.

Penelitian eksperimen ini dilaksanakan melalui beberapa tahapan. Tahap pertama, menyusun asesment penilaian berupaangket bakat kinestetikdan rubrik kinerja kemampuan smash bola voli serta telah mendapatkan pemeriksaan dari satu orang ahli (judges). Tahap 
kedua, uji coba angket dan rubrik kinerja kemampuan smash bola voli. Tahap Ketiga, pengumpulan data awal yang dilanjutkan dengan tahap pelaksanaan eksperimen yang dilakukan dengan melaksanakan latihan (perlakuan) pada siswa kelompok eksperimen dan kelompok kontrol sesuai dengan rencana latihan yang telah disusun.

Pada kelompok eksperimen menggunakan latihan smash bola voli dalam posisi bergerak sedangkanpadakelompok kontrol menggunakan latihan smash bola voli dalam posisi diam. Selanjutnya disebarkan tes kemampuan awal smash bola voli pada kelompok eksperimen maupun kelompok kontrol untuk memperoleh data siswa pada kedua kelompok.

Data yang diperoleh selanjutnya ditabulasi menjadi empat kelompok data. Empat kelompok data tersebut adalah sebagai berikut.

1. Kemampuan Smash Bola Voli yang Memiliki Bakat Kinestetik
Tinggi yang Mengikuti Latihan dalam Posisi Bergerak

2. Kemampuan Smash Bola Voli yang Memiliki Bakat Kinestetik Rendah yang Mengikuti Latihan dalam Posisi Bergerak

3. Kemampuan Smash Bola Voli yang Memiliki Bakat Kinestetik Tinggi yang Mengikuti Latihan dalam Posisi Diam

4. Kemampuan Smash Bola Voli yang Memiliki Bakat Kinestetik Rendah yang Mengikuti Latihan dalam Posisi Diam

\section{HASIL DAN PEMBAHASAN \\ Hasil}

Adapun hasil penelitian dapat ditinjau dari hasil hasil analisis uji anava dua jalur yang telah dilakukan terhadap seluruh data-data yang telah diperoleh pada penelitian ini yang disajikan pada Tabel 1.1Ringkasan Hasil Uji Univariate, untuk pengujian hipotesis pertama $\left(\mathrm{H}_{1}\right)$, kedua $\left(\mathrm{H}_{2}\right)$ dan ketiga $\left(\mathrm{H}_{3}\right)$.

Tabel 1 Ringkasan Hasil Uji Hipotesis

\begin{tabular}{llllll}
\hline \multicolumn{1}{c}{ Source } & $\begin{array}{c}\text { Type III Sum of } \\
\text { Squares }\end{array}$ & Df & $\begin{array}{c}\text { Mean } \\
\text { Square }\end{array}$ & F & Sig. \\
\hline Corrected Model & $1673.662^{\mathrm{a}}$ & 3 & 557.887 & 10.332 & 0.000 \\
Intercept & 33773.863 & 1 & 33773.863 & 625.511 & 0.000 \\
$M L S B V$ & 382.333 & 1 & 382.333 & 7.081 & 0.012 \\
BK & 417.930 & 1 & 417.930 & 7.740 & 0.009 \\
$M L S B V^{*} B K$ & 873.400 & 1 & 873.400 & 16.176 & 0.000 \\
Error & 1727.808 & 32 & 53.994 & & \\
Total & 37175.334 & 36 & & & \\
Corrected Total & 3401.471 & 35 & & & \\
\hline
\end{tabular}

Berdasarkan Tabel 1 Ringkasan Hasil Uji Hipotesis, maka dirumuskan hasil uji hipotesis sebagai berikut.

1. Hasil Uji Hipotesis Pertama

Nilai rata-rata terestimasi $(\mu)$ dan standar deviasi (SD)variabel kemampuan smash bola voli kelompok metode latihan smash bola voli posisi bergerak dan metode latihan smash bola voli posisi diam disajikan pada Tabel 2. 
Tabel 2. Nilai Rata-Rata Terestimasi dan Standar Deviasi Variabel Kemampuan Smash Bola Voli untuk Kelompok Metode Latihan Smash Bola Voli.

\begin{tabular}{cccccc}
\hline $\begin{array}{c}\text { Variabel } \\
\text { Dependen }\end{array}$ & $\begin{array}{c}(\mathbf{I}) \\
\text { MLSBV }\end{array}$ & $\begin{array}{c}(\mathbf{J}) \\
\mathbf{M L S B V}\end{array}$ & $\begin{array}{c}\boldsymbol{\mu}(\mathbf{I})-\boldsymbol{\mu}(\mathbf{J}) \\
(\Delta \boldsymbol{\mu})\end{array}$ & SD & Sig. \\
\hline \multirow{2}{*}{ KSBV } & $(\mathbf{2})$ & $(\mathbf{3})$ & $(\mathbf{4})$ & $\mathbf{( 5 )}$ & $(\mathbf{6})$ \\
\hline
\end{tabular}

Berdasarkan Tabel 2, tampak bahwa perbedaan nilai rata-rata Kemampuan Smash Bola Voli adalah $\Delta \mu(K S B V)==6,518$ dengan standar deviasi $\mathrm{SD}=2,449$ dan angka signifikansi lebih kecil dari 0,05 . Di samping itu, $\Delta \mu(K S B V)==$ 6,518 lebih besar dari LSD (KSBV) $=4,996$. Jadi nilai rata-rata Kemampuan Smash Bola Voli kelompok MLSBVPB dan kelompok MLSBVPD adalah berbeda signifikan. Nilai rata-rata KSBVkelompok MLSBVPB secara statistik lebih tinggi dibandingkan dengan kelompok MLSBVPD.

\section{Hasil Uji Hipotesis Kedua}

Nilai rata-rata terestimasi $(\mu)$ dan standar deviasi (sd) kemampuan smash bola voli siswa yang memiliki bakat kinestetik tinggi dan bakat kinestetik rendah kelompok metode latihan smash bola voli posisi bergerak dan metode latihan smash bola voli posisi diam disajikan pada tabel 3.

Tabel 3. Nilai Rata-Rata Terestimasi dan Standar Deviasi Variabel Kemampuan Smash Bola Voli untuk Bakat Kinestetik Siswa.

\begin{tabular}{|c|c|c|c|c|c|}
\hline $\begin{array}{l}\text { Variabel } \\
\text { Dependen }\end{array}$ & $\begin{array}{l}\text { (I) } \\
\text { BK }\end{array}$ & $\begin{array}{l}(\mathbf{J}) \\
\text { BK }\end{array}$ & $\begin{array}{c}\boldsymbol{\mu}(\mathbf{I})-\boldsymbol{\mu}(\mathbf{J}) \\
(\Delta \boldsymbol{\mu})\end{array}$ & SD & Sig. \\
\hline (1) & (2) & (3) & (4) & (5) & (6) \\
\hline KSBV & $\begin{array}{l}1.00(\mathrm{BKT}) \\
2.00(\mathrm{BKR})\end{array}$ & $\begin{array}{l}2.00(\mathrm{BKR}) \\
1.00(\mathrm{BKT})\end{array}$ & $\begin{array}{l}6.814^{*} \\
-6.814^{*}\end{array}$ & $\begin{array}{l}2.449 \\
2.449\end{array}$ & $\begin{array}{l}0.009 \\
0.009\end{array}$ \\
\hline
\end{tabular}

Berdasarkan tabel 3 menunjukkan bahwa, terdapat perbedaan kemampuan smash bola voli antara siswa yang memiliki bakat kinestetik tinggi dan siswa yang memiliki bakat kinestetik rendah. Ditinjau dari nilai rata-rata kemampuan smash bola voli siswa yang memiliki bakat kinestetik tinggi dan bakat kinestetik rendah adalah $\Delta \mu(K S B V)=6,814 \quad$ dengan standar deviasi $\mathrm{SD}=2,449$ dan angka signifikansi lebih kecil dari 0,05 . Di samping itu, $\Delta \mu(K S B V)=6,814$ lebih besar dari LSD (Kemampuan Smash Bola Voli $)=4,996$. Jadi nilai rata-rata Kemampuan Smash Bola Voli siswa yang memiliki bakat kinestetik tinggi dan bakat kinestetik rendah adalah berbeda secara signifikan. Nilai ratarata kemampuan smash bola voli siswa yang memiliki bakat kinestetik tinggi secara statistik lebih tinggi dibandingkan dengan nilai rata-rata kemampuan smash bola voli siswa yang memiliki bakat kinestetik rendah. 
3. Hasil Uji Hipotesis Ketiga

Berdasarkan pengujian hipotesis yang ketiga dalam pencapaian kemampuan smash bola voli siswa, metode latihan smash bola voli dan bakat kinestetik berinteraksi secara signifikan $(\mathrm{p}<0,05)$. Profil pola interaksi antara kedua variabel independen tersebut tampaknya penting untuk ditampilkan. Tampilan tersebut akan memberikan gambaran visual salah satu di antara (MLSBVPB) dan (MLSBVPD) yang paling akomodatif sebagai metode latihan yang diterapkan pada siswa yang memiliki bakat kinestetik tinggi atau bakat kinestetik rendah dalam pencapaian kemampuan smash bola voli. Tampilan grafik interaksi metode latihan dan bakat kinestetikdalam pencapaian kemampuan smash bola voli yang merupakan output program SPSS 22.0 for windows disajikan seperti pada Gambar 2.

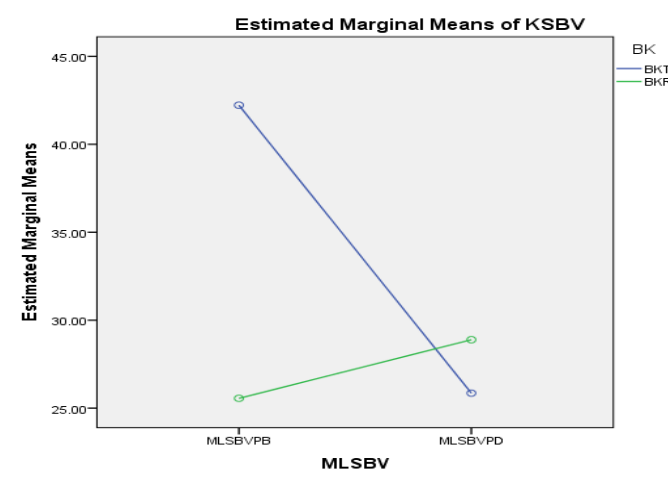

Gambar 2. Grafik Interaksi Variabel Metode Latihan dengan bakat Kinestetik dalam Pencapaian Kemampuan Smash Bola Voli

\section{Keterangan:}

MLSBVPB =metode latihan smash bola voli posisi bergerak

Rerata: MLSBVPB-BKT $=42,221$ MLSBVPD = metode latihan smash bola voli posisi diam
MLSBVPB-BKR= 25,556

BKT = bakat kinestetik tinggi

MLSBVPD-BKT $=25,852$

BKR $=$ bakat kinestetik rendah

MLSBVPD-BKR= 28,889

\section{Pembahasan}

Dari hasil penelitian dapat disimpulkan bahwa, perbedaan metodelatihan dalam posisi bergerak dengan bakat kinestetik tinggi secara signifikan memiliki pengaruh lebih baik dibandingkan dengan model latihan dalam posisi diamdalam pencapaian kemampuan smash bola voli.

Sejalan dengan penelitian yang dilakukan oleh BowlesTerry (2012) dalam penelitiannya menunjukkan bahwa peringkat tertinggi adalah bakat aktivitas fisik dan olahraga, bahasa dan komunikasi. Talenta antara tingkat tahun (muda atau tua) dan klaster (rendah atau tinggi) menunjukkan hanya satu interaksi dimana bakat yang dirasakan rendah siswa yang lebih tua yang dilematis rendah kesadaran diri. Dari hasil penelitian dapat disimpulkan bahwa bakat memiliki pengaruh signifikan terhadap kinerja belajar siswa.

Penelitian yang dilakukan oleh Schneider (2011) dalam penelitiannya menunjukkan bahwa pengguaan metode belajar kinestetik oleh Guru SD di desa Chicagodaerah Oak Parkuntuk dapat melibatkan peran aktif Guru dan siswa dalam proses pembelajaran efektif untuk diterapkan dalam pembelajaran yang berhubungan dengan kemampuan fisik. Penelitian ini membuktikan bahwa pengaruh model pembelajaran kooperatif dan bakat kinestetik mempunyai jalinan 
yang efektif untuk meningkatkan prestasi belajar.

Selanjutnya penelitian oleh Sarwa (2010) menunjukkan bahwa mahasiswa yang mempunyai bekal bakat kinestetik lebih tinggi, maka dalam pembelajaran dengan kondisi yang sama, akan memberikan prestasi belajar yang lebih tinggi pula .Berdasarkan dari hasil kajian yaitu adanya penerapan bakat kinestetik serta tinjauannya terhadap prestasi belajar yang diterapkan dalam penelitian. Dengan demikian adanya kesesuaian anatara penerapan bakat kinestetik yang berhubungan dengan kegiatan praktik pembelajaran yang bermuara pada pencapaian prestasi belajar.

Jadi, dengan demikian dalam kajian ini, di dalam era informasi sekarang ini seharusnya telah terjadi suatu perubahan peranan guru. Dimana guru tidak lagi berperan sebagai satu-satunya sumber belajar (learning resources), akan tetapi lebih berperan sebagai pengelola pembelajaran (manager of instruction) untuk meningkatkan mutu pembelajaran seingga bermuara pada keberhasilan belajar.

\section{PENUTUP}

\section{Simpulan}

Penelitian ini mengarah pada perbedaan latihan dan bakat kinestetik terhadap kemampuan smash bola voli SD Negeri 1 Pelapuan, maka dapat disimpulkan sebagai berikut:

1. Perbedaan latihan berpengaruh signifikan terhadap kemampuan smash bola voli pada siswa SD Negeri 1 Pelapuan.

2. Terdapat perbedaan kemampuan smash bola voli antara siswa yang memiliki bakat kinestetik tinggi dengan siswa yang memiliki bakat kinesteti rendah

3. Terdapat intraksi antara perbedaan latihan dan bakat kinestetik terhadap kemampuan smash bola voli.

\section{Saran}

Adapun saran yang perlu peneliti sampaikan sesuai dengan hasil penelitian ini adalah:

1. Perlu penelitian lebih lanjut mengenai perbedaan latihan dan bakat kinestetik khususnya pada suatu cabang olahraga yang lain dengan penambahan variasi latihan serta kondisi sampel yang berbeda.

2. Bagi para pendidik, dapat menyusun program latihan dan mampu memperhatikan karakteristik belajar siswa sehingga siswa sehingga proses latihan dapat berjalan sesuai dengan harapan dan mencapai hasil yang maksimal.

3. Dengan adanya perbedaan latihan dan bakat kinestetik dalam penelitian ini seyogyanya dapat direkomendasikan ataupun diterapkan pada proses pembelajaran permainan bola voli sehingga dapat meningkatkan kemampuan smash bola voli.

\section{DAFTAR PUSTAKA}

Bowles Terry. 2012. The longer they stay the less talented they perceive they are: Females talent based on approaches to learning. Australian Journal of Educational \& Developmental Psychology. pp. 12-20 (12). 1-20. Tersedia pada:

www.newcastle.edu.au/journa 1/ajedp/. Diakses pada tanggal: 28 Desember 2013. 
Candiasa,M. 2010. Pengujian Instrumen Penelitian Disertasi Aplikasi Itemen Dan Bigsteps.Singaraja: Undiksha.

Candiasa, M. 2010. Statistik Univariat dan Bivariat Disertasi Aplikasi SPSS. Singaraja: Undiksha.

Depdiknas. 2003. Undang-Undang Republik Indonesia Nomor 14 Tahun 2005 Tentang Guru dan Dosen.

Khurshid, F. 2012. Learning styles of natural sciences, social sciences and humanities students at graduate level. Interdisciplinary Journal of Contemporary Research in Business. 3. (9). 672-678. Tersedia pada:http://www. journalarchieves14.webs.com 1672678.df.Diakses pada Tanggal: 25 November 2013.

Ronald, M. G. 1976. Information Processing in Motor Skill. New York: Holt, Rinehart and Winston.

Sarwa I N. 2010. Determinasi Potensi Akademik, Bakat Kinestetik, dan Motivasi Berprestasi Terhadap Prestasi Belajar Kerawitan pada
Mahasiswa Jurusan

Karawitan Fakultas Seni

Pertunjukan Institut Seni

Indonesia Denpasar. Jurnal penelitian pasca sarjana Undiksha. 7,(1) 1-15. Tersedia pada:http://pasca.undiksha.ac. id/ejournal/index.php/jurnalp p/article/view/23/23. Diakses Pada tanggal: 25 Februari 2014.

Sarwono, S. W. 1977. Psikologi Remaja. Jakarta: Gramedia.

Santyasa, I W. 2012. Seri Buku Ajar Perguruan Tinggi: Pembelajaran Inovatif. Undiksha Press.

Schneider, S. K. 2011.Wise teaching to students kinesthetic intelligence: The teacher as surrogate, Guru, foreshadower, choreographer, or expeditionist. Journal of the Assembly for Expanded Perspectives on Learning. 16. 23-39.

Tersedia pada:http://trace.tennessee.ed u/cgi/viewcontent.cgi?article $=1190 \&$ context $=$ jaepl. Diakse spada Tanggal 1 Oktober 2013. 